Article

\title{
Synthesis and Biological Evaluation of Novel 8-Morpholinoimidazo[1,2-a]pyrazine Derivatives Bearing Phenylpyridine/Phenylpyrimidine- Carboxamides
}

\author{
Shan $\mathrm{Xu}{ }^{1}$, Chengyu Sun ${ }^{1,2, *}$, Chen Chen ${ }^{1}$, Pengwu Zheng ${ }^{1}$, Yong Zhou ${ }^{2}$, Hongying Zhou ${ }^{2}$ and \\ Wufu Zhu ${ }^{1, *}$ \\ 1 School of Pharmacy, Jiangxi Science \& Technology Normal University, Nanchang 330013, China; \\ Shanxu9891@126.com (S.X.); chen5950677@163.com (C.C.); Zhengpw@126.com (P.Z.) \\ 2 Department of Pharmacy, The Affiliated Hospital of Chongqing Three Gorges Medical College, \\ Chongqing 404000, China; zhouyong_0801@126.com (Y.Z.); 15223632072@163.com (H.Z.) \\ * Correspondence: sunchengyu0902@126.com (C.S.); zhuwufu-1122@163.com (W.Z.); \\ Tel./Fax: +86-791-8380-2393 (W.Z.)
}

Academic Editor: Diego Muñoz-Torrero

Received: 29 December 2016; Accepted: 15 February 2017; Published: 17 February 2017

\begin{abstract}
Herein we designed and synthesized three series of novel 8-morpholinoimidazo[1,2- $a$ ] pyrazine derivatives bearing phenylpyridine/phenylpyrimidine-carboxamides (compounds 12a-g, 13a-g and 14a-g). All the compounds were evaluated for their $\mathrm{IC}_{50}$ values against three cancer cell lines (A549, PC-3 and MCF-7). Most of the target compounds exhibited moderate cytotoxicity against the three cancer cell lines. Two selected compounds 14b, 14c were further tested for their activity against PI $3 \mathrm{~K} \alpha$ kinase, and the results indicated that compound $14 \mathrm{c}$ showed inhibitory activity against PI3K $\alpha$ kinase with an $\mathrm{IC}_{50}$ value of $1.25 \mu \mathrm{M}$. Structure-activity relationships (SARs) and pharmacological results indicated that the replacement of the thiopyranopyrimidine with an imidazopyrazine was beneficial for the activity and the position of aryl group has a significant influence to the activity of these compounds. The compounds 13a-g in which an aryl group substituted at the C-4 position of the pyridine ring were more active than 12a-g substituted at the C-5 position. Moreover, the cytotoxicity of compounds 14a-g bearing phenylpyrimidine-carboxamides was better than that of the compounds $12 \mathbf{a}-\mathbf{g}, 13 \mathbf{a}-\mathbf{g}$ bearing phenylpyridine-carboxamides. Furthermore, the substituents on the benzene ring also had a significant impact on the cytotoxicity and the pharmacological results showed that electron donating groups were beneficial to the cytotoxicity.
\end{abstract}

Keywords: imidazopyrazine; phenylpyridine-carboxamide; phenylpyrimidine-carboxamide; $\mathrm{PI} 3 \mathrm{~K} \alpha$; synthesis

\section{Introduction}

At present, with the in-depth study of cancer pathogenesis at the molecular level, molecular targeted therapy has become a research hotspot. Numerous molecular signaling pathways have been shown to be associated with the development and progression of cancer. The PI3K-Akt-mTOR signaling pathway is one of them, which was found frequently activated in different cancers. It can promote the development of tumor by inhibiting cell apoptosis, promoting angiogenesis, cell proliferation and invasion [1,2]. Therefore, the inhibition of the PI3K-Akt-mTOR pathway can effectively suppress the occurrence and development of cancer. Currently, a number of inhibitors acting on this pathway have been reported, such as PI-103, GDC-0941, MLN0128, PKI-587 and ETP46992 [3-7] (Figure 1). Among them, PI-103 was the first PI3K/mTOR dual inhibitor with IC $_{50}$ values of 8 and $20 \mathrm{nM}$ against PI3K $\alpha$ 
and mTOR, respectively [3]. GDC-0941 was the first PI3K inhibitor entering clinical studies and was developed by Genentech based on the modification and optimization of PI-103 [4].

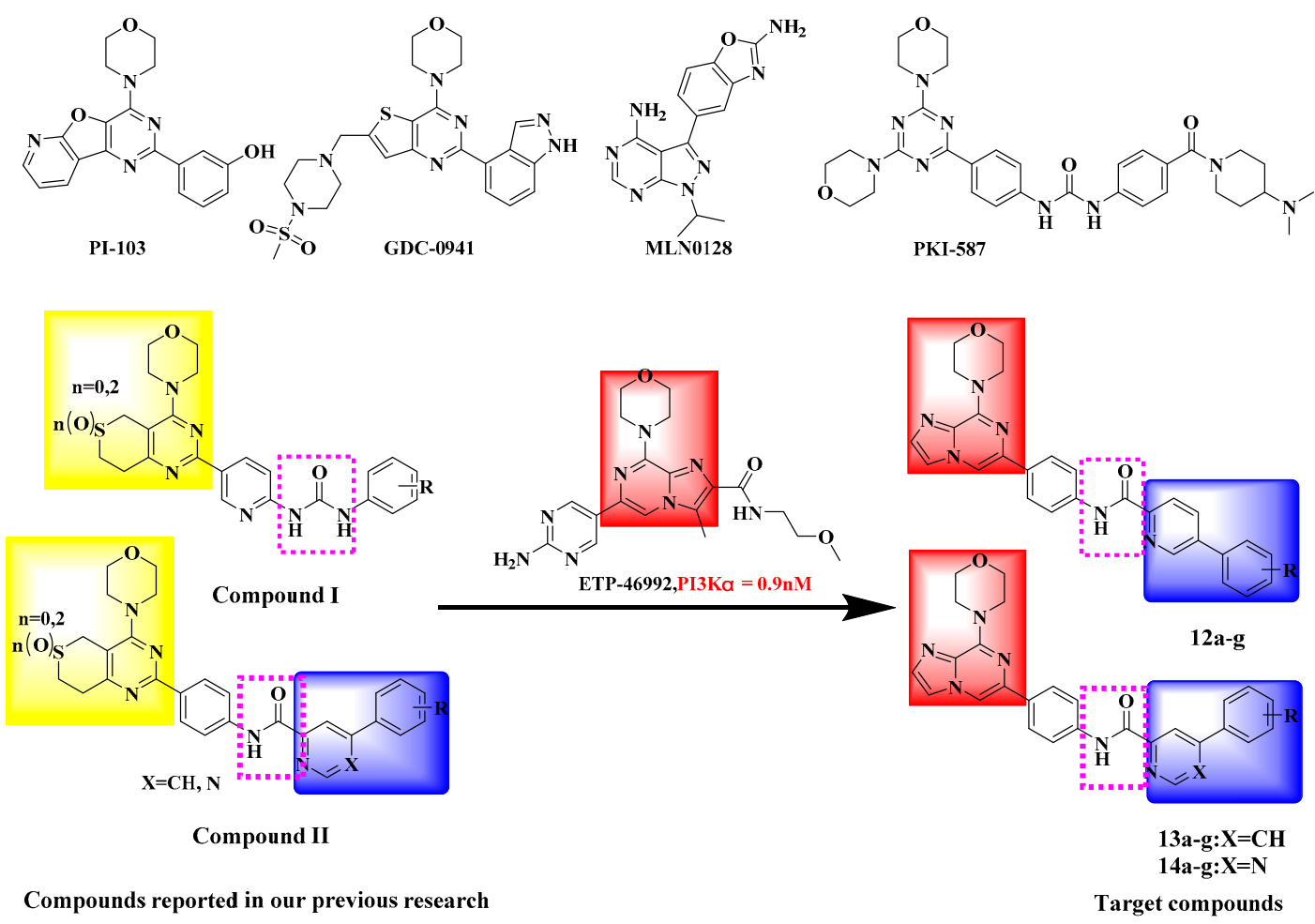

Figure 1. Structures of some reported PI3K pathway inhibitors and design strategy of the target compounds.

In our previous research [8-11], several series of thiopyranopyrimidine derivatives were designed and synthesized as PI3K-Akt-mTOR pathway inhibitors, such as compound I and compound II. In order to screen for compounds with excellent anti-tumor activity, further studies on these compounds were carried out in this research. According to the reported PI3K pathway inhibitors, we found that most of them contained (fused-)pyrimidine/pyrazine skeleton structure and the SARs results indicated that this skeleton was beneficial to the activity. Therefore, we replaced the thiopyranopyrimidine with an imidazopyrazine inspired by ETP46992 which is a PI3K $\alpha$ inhibitor with an IC $_{50}$ value of $0.9 \mathrm{nM}$. In addition, we maintained the amide scaffold based on the SARs results of our previous research. Then, we changed the position of aryl group on the pyridine/pyrimidine to investigate the effect on activity. Lastly, we introduced various substituents on the benzene ring to investigate their effect on anti-tumor activity. As a result, three series of 8-morpholinoimidazo[1,2-a]pyrazine derivatives bearing phenylpyridine-carboxamides or phenylpyrimidine-carboxamides were designed and synthesized. The design strategy for all target compounds is shown in Figure 1.

Herein, we report the design, synthesis and the cytotoxicity of all target compounds against three human cancer cell lines A549 (lung cancer), PC-3 (prostate cancer), and MCF-7 (breast cancer), as well as the activity of two selected compounds $14 \mathrm{~b}, 14 \mathrm{c}$ against PI3K $\alpha$ kinase. In addition, a molecular modeling docking study of the most promising compound $14 \mathrm{c}$ with PI3K $\alpha$ kinase was performed.

\section{Results and Discussion}

The preparations of target compounds $12 \mathbf{a}-\mathbf{g}, 13 \mathbf{a}-\mathbf{g}$ and $14 \mathbf{a}-\mathbf{g}$ were described in Scheme 1. The key intermediate 5 was synthesized from 2-aminopyrazine in five steps. The 2-aminopyrazine was brominated to yield 3,5-dibromopyrazin-2-amine (1) and the 3-bromine atom was then substituted with morpholine to give compound 2. Subsequently, compound $\mathbf{2}$ was cyclized with 
chloroacetaldehyde to give compound 3. Compound 3 was coupled with $p$-bromonitrobenzene by Suzuki coupling and then reduced with hydrazine hydrate to obtain the key intermediate compound 5. The 5-(substituted phenyl)picolinic acids $6 \mathbf{a}-\mathbf{g}$, 4-(substituted phenyl)picolinic acids 7a-g and 6-(substituted phenyl)pyrimidine-4-carboxylic acids 8a-g were synthesized through the procedures reported in our previous research [11,12]. Carboxylic acids $\mathbf{6 a}-\mathbf{g}, \mathbf{7 a -} \mathbf{\mathbf { g }}$ and $\mathbf{8 a}-\mathbf{g}$ were converted into the corresponding acyl chlorides and then immediately amidated with compound 5 to obtain the target compounds 12a-g, 13a-g and 14a-g, respectively (Scheme 1). The yields for each target compound are listed in Table 1.
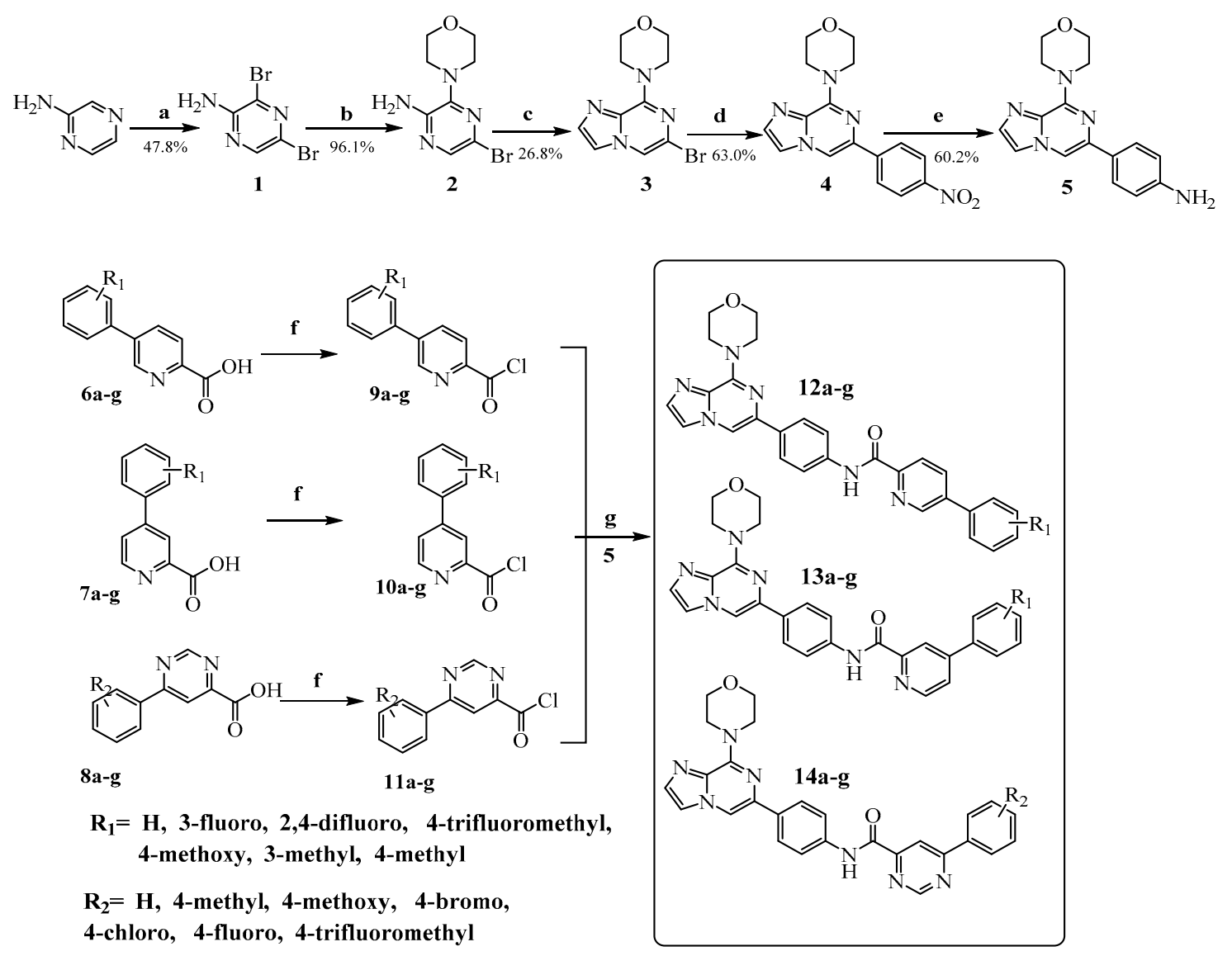

Scheme 1. Synthetic routes of target compounds $12 \mathrm{a}-\mathrm{g}, 13 \mathrm{a}-\mathrm{g}$ and $14 \mathrm{a}-\mathrm{g}$. Reagents and conditions: (a) $\mathrm{Br}_{2}$, pyridine, $\mathrm{CH}_{2} \mathrm{Cl}_{2}, 40{ }^{\circ} \mathrm{C}, 1.5 \mathrm{~h}$; (b) morpholine, $80{ }^{\circ} \mathrm{C}$, reflux, $1 \mathrm{~h}$; (c) chloroacetaldehyde, isopropanol, $45^{\circ} \mathrm{C} \sim 65^{\circ} \mathrm{C}$, $2 \mathrm{~h}$; (d) (1) bis(pinacolato)diboron, $\mathrm{KAc}, \mathrm{Pd}\left(\mathrm{PPh}_{3}\right) \mathrm{Cl}_{2}, p$-bromonitrobenzene, 1,2-dimethoxyethane, reflux, 2-3 h; (2) $\mathrm{H}_{2} \mathrm{O}, \mathrm{Na}_{2} \mathrm{CO}_{3}, \mathrm{Pd}\left(\mathrm{PPh}_{3}\right)_{2} \mathrm{Cl}_{2}$, reflux, 6-8 h; (e) hydrazine hydrate, $\mathrm{FeCl}_{3}$, Activated carbon, ethanol, reflux, 1-3 h; (f) thionyl chloride, reflux, $1 \mathrm{~h}$; (g) DIPEA, $\mathrm{CH}_{2} \mathrm{Cl}_{2}, 0.5 \mathrm{~h}$.

\subsection{Biological Evaluation}

The target compounds 12a-g, 13a-g and 14a-g were evaluated for their in vitro cytotoxicity against three cancer cell lines (A549, PC-3 and MCF-7) by the standard MTT assay, with compound II and GDC-0941 as positive controls. Two selected compounds $(\mathbf{1 4 b}, \mathbf{1 4} \mathbf{c})$ were further tested for PI3K $\alpha$ kinase inhibitory activity together with reference compound II, GDC-0941 and PI-103 by a Kinase-Glo ${ }^{\circledR}$ Luminescent Kinase Assay. The results expressed as inhibition rates or $\mathrm{IC}_{50}$ values are summarized in Tables 1 and 2, where the values are the average of at least two independent experiments. 
Table 1. Structures and cytotoxicity of target compounds $12 \mathrm{a}-\mathrm{g}, 13 \mathrm{a}-\mathrm{g}$ and $14 \mathrm{a}-\mathrm{g}$.

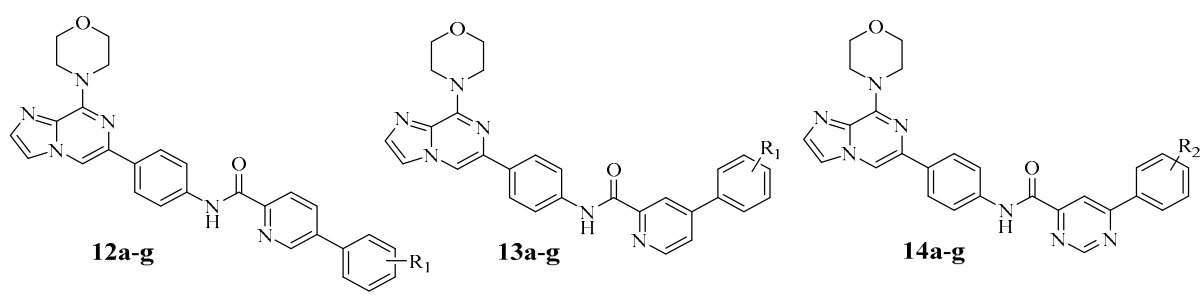

\begin{tabular}{|c|c|c|c|c|c|}
\hline \multirow{2}{*}{ Compd. } & \multirow{2}{*}{$\mathbf{R}$} & \multirow{2}{*}{ Yield (\%) } & \multicolumn{3}{|c|}{$\mathrm{IC}_{50}(\mu \mathrm{M})^{\mathrm{a}}$} \\
\hline & & & A549 & PC-3 & MCF-7 \\
\hline $12 a$ & $\mathrm{H}$ & 96.1 & $58.73 \pm 1.99$ & $50.28 \pm 2.04$ & ND \\
\hline $12 b$ & 3-fluoro & 79.4 & NA & NA & NA \\
\hline $12 \mathrm{c}$ & 2,4-difluoro & 90.2 & NA & NA & NA \\
\hline $12 d$ & 4-trifluoromethyl & 83.5 & $15.27 \pm 0.88$ & $69.70 \pm 1.13$ & ND \\
\hline $12 e$ & 4-methoxy & 93.3 & NA & NA & NA \\
\hline $12 f$ & 3-methyl & 72.6 & $19.11 \pm 1.10$ & $26.78 \pm 1.47$ & ND \\
\hline $12 \mathrm{~g}$ & 4-methyl & 89.1 & $68.12 \pm 0.89$ & $42.32 \pm 0.86$ & ND \\
\hline $13 a$ & $\mathrm{H}$ & 97.0 & NA & NA & NA \\
\hline $13 b$ & 3-fluoro & 88.0 & NA & NA & NA \\
\hline $13 c$ & 2,4-difluoro & 91.2 & NA & NA & NA \\
\hline $13 d$ & 4-trifluoromethyl & 81.8 & $41.99 \pm 1.49$ & $55.64 \pm 1.32$ & $62.48 \pm 1.99$ \\
\hline $13 e$ & 4-methoxy & 93.1 & $23.95 \pm 0.81$ & $59.68 \pm 2.22$ & $74.92 \pm 1.14$ \\
\hline $13 \mathrm{f}$ & 3-methyl & 91.5 & $10.53 \pm 0.82$ & $65.61 \pm 0.52$ & $74.19 \pm 1.86$ \\
\hline $13 \mathrm{~g}$ & 4-methyl & 98.0 & $11.23 \pm 1.08$ & NA & $7.89 \pm 0.81$ \\
\hline $14 a$ & $\mathrm{H}$ & 82.7 & $10.75 \pm 1.62$ & NA & NA \\
\hline $14 b$ & 4-methyl & 79.5 & $8.88 \pm 0.97$ & $25.04 \pm 1.19$ & $6.69 \pm 2.04$ \\
\hline $14 \mathrm{c}$ & 4-methoxy & 77.8 & $6.39 \pm 1.04$ & $12.65 \pm 0.95$ & $10.23 \pm 1.62$ \\
\hline $14 d$ & 4-bromo & 90.9 & $14.36 \pm 1.01$ & $37.14 \pm 0.97$ & NA \\
\hline $14 \mathrm{e}$ & 4-chloro & 93.2 & $17.38 \pm 1.01$ & NA & NA \\
\hline $14 \mathrm{f}$ & 4-fluoro & 80.8 & $58.17 \pm 4.67$ & NA & 47.06 \\
\hline $14 \mathrm{~g}$ & 4-trifluoromethyl & 77.6 & NA & $96.63 \pm 2.58$ & ND \\
\hline Compound II ${ }^{b, c}$ & - & - & $8.37 \pm 0.10$ & $11.34 \pm 0.11$ & $9.26 \pm 0.82$ \\
\hline GDC-0941 b & - & - & $6.99 \pm 0.21$ & $0.20 \pm 0.08$ & $0.07 \pm 0.03$ \\
\hline
\end{tabular}

${ }^{a}$ The values are an average of two separate determinations; ${ }^{b}$ Used as a positive control; ${ }^{\mathrm{c}}$ Compounds reported in our previous research; NA: No Activity; ND: Not Determine.

Table 2. PI3K $\alpha$ kinase activity of selected compounds and positive controls.

\begin{tabular}{cc}
\hline Compound No. & PI3K $\alpha$ \\
\cline { 2 - 2 } & IC $_{\mathbf{5 0}}(\boldsymbol{\mu M})^{\text {a }}$ or $\mathbf{1 0} \boldsymbol{\mu M}$ Inhibitory $\mathbf{o}^{\mathbf{a}}$ \\
\hline 14b & $58.0 \pm 4.4 \cong 10 \mu \mathrm{M}$ \\
14c & $1.25 \pm 0.13$ \\
Compound II $^{\mathrm{b}, \mathrm{c}}$ & $7.39 \pm 0.19[11]$ \\
GDC-0941 $^{\mathrm{b}}$ & $0.003[4]$ \\
PI-103 $^{\mathrm{b}}$ & $0.075 \pm 0.018$
\end{tabular}

\footnotetext{
a The values are an average of two separate determinations; ${ }^{b}$ Used as a positive control; ${ }^{c}$ Compounds reported in our previous research.
}

From Table 1, we can see that most of the target compounds showed moderate cytotoxicity against the three cancer cell lines, with $\mathrm{IC}_{50}$ values ranging from 6.39 to $74.9 \mu \mathrm{M}$ and most of them showed more activity against the A549 cancer cell line than the other two cancer cell lines (PC-3, MCF-7). The $\mathrm{IC}_{50}$ values of the most promising compound $14 \mathrm{c}$ against the $\mathrm{A} 549$ cancer cell lines was 6.39 $\mu \mathrm{M}$, which was superior to the previously prepared compound II ( $\mathrm{IC}_{50}$ values $\left.8.37 \mu \mathrm{M}\right)$. This means that the replacement of the thiopyranopyrimidine with an imidazopyrazine was beneficial to the cytotoxicity. Comparing the activity of the three series of target compounds, we found that an aryl group at the pyridine C-4 position (compounds 13a-g) was more active than that at the C-5 position (compounds 12a-g). Besides, the data of Table 1 show that the cytotoxicity of compounds 14a-g 
bearing a phenylpyrimidine-carboxamides was better than that of compounds $12 \mathbf{a}-\mathbf{g}, \mathbf{1 3 a}-\mathbf{g}$ bearing a phenylpyridine-carboxamide. In addition, due to the different substituents on the benzene ring, the cytotoxicity of the same class of compounds varied too. The results showed that the compounds containing electron donating groups (i.e., $12 \mathbf{e}-\mathbf{g}, \mathbf{1 3 e}-\mathbf{g}$ and $\mathbf{1 4 a}-\mathbf{c}$ ) exhibited higher cytotoxicity than the compounds containing electron-withdrawing ones (i.e., $\mathbf{1 2 b}-\mathbf{d}, \mathbf{1 3} \mathbf{b}-\mathbf{d}$ and $\mathbf{1 4} \mathbf{d}-\mathbf{g}$ ).

The activity of the selected compounds $14 \mathrm{~b}, \mathbf{1 4} \mathrm{c}$ as well as the positive control compounds against the PI3K $\alpha$ kinase is shown in Table 2. The activity of compound $\mathbf{1 4 b}$ against PI3K $\alpha$ kinase was moderate, with an inhibitory value of $58.0 \%$ at $10 \mu \mathrm{M}$. The most promising compound $14 \mathrm{c}$ showed an $\mathrm{IC}_{50}$ value of $1.25 \mu \mathrm{M}$ against PI3K $\alpha$ kinase, which was 6-fold more active than the lead compound II $\left(\mathrm{IC}_{50}\right.$ values $\left.7.39 \mu \mathrm{M}\right)$. This indicated that the replacement of the thiopyranopyrimidine structure with the imidazopyrazine moiety enhanced the activity against PI3K $\alpha$ kinase.

As described above, the replacement of the thiopyranopyrimidine with an imidazopyrazine was beneficial to the activity of these derivatives. In addition, the series of compounds bearing phenylpyrimidine-carboxamide structures showed the best activity among all three series of target compounds. Moreover, electron donating substituents on the benzene ring were beneficial to the cytotoxicity. Comparing Tables 1 and 2, we found that the differences in cytotoxicity between compounds 14b and 14c were not particularly significant, but they were significant for PI3K $\alpha$ activity. This suggested that compound $\mathbf{1 4 b}$ may have potential activity on other targets, which may be an interesting direction in our future studies.

\subsection{Molecular Docking Study}

To explore the binding modes of the target compounds with the active site of $\mathrm{PI} 3 \mathrm{~K} \alpha$, molecular docking simulation studies were carried out by using the SURFLEX-DOCK module of the SYBYL software package. Based on the results of the in vitro activity tests, we selected compound $14 \mathrm{c}$ as a ligand example, and the structure of PI3K $\alpha$ (PDB ID code: 4L23) was selected as the docking model $[9,10]$.

The binding mode of compound $\mathbf{1 4} \mathbf{c}$ with PI3K $\alpha$ is shown in Figure 2a,b. As depicted in Figure 2a, the imidazopyrazine scaffold and morpholine group of compound $\mathbf{1 4} \mathrm{c}$ were tightly packed into the channel formed by the amino acid residues of PI3K $\alpha$. We found that the compound $14 \mathrm{c}$ formed two hydrogen bonds with residues of the PI3K $\alpha$ molecule: the oxygen atom of morpholine with the Val851 residue and the carbonyl of the amide scaffold with the SER773 residue.

This result indicates that the morpholine and the amide scaffold are very important to maintain the activity against PI3K $\alpha$ kinase of the target compounds. In addition, according to the comparison of docking results of the compound 14c and PI-103 (Figure 2b), we see that the main skeleton structures of compound 14c and the PI-103 molecule scaffold were almost completely overlapped, especially the morpholine group. This result suggested that the replacement of the thiopyranopyrimidine with an imidazopyrazine was advantageous in improving the activity. What's more, the docking results also suggest that the benzene ring of phenylpyridine/phenylpyrimidine cannot bind well to PI3K $\alpha$, which may be one reason why the anti-tumor activity of these compounds is not particularly good. For this reason, we may be able to improve the anti-tumor activity of them by modify this part in the future work. 


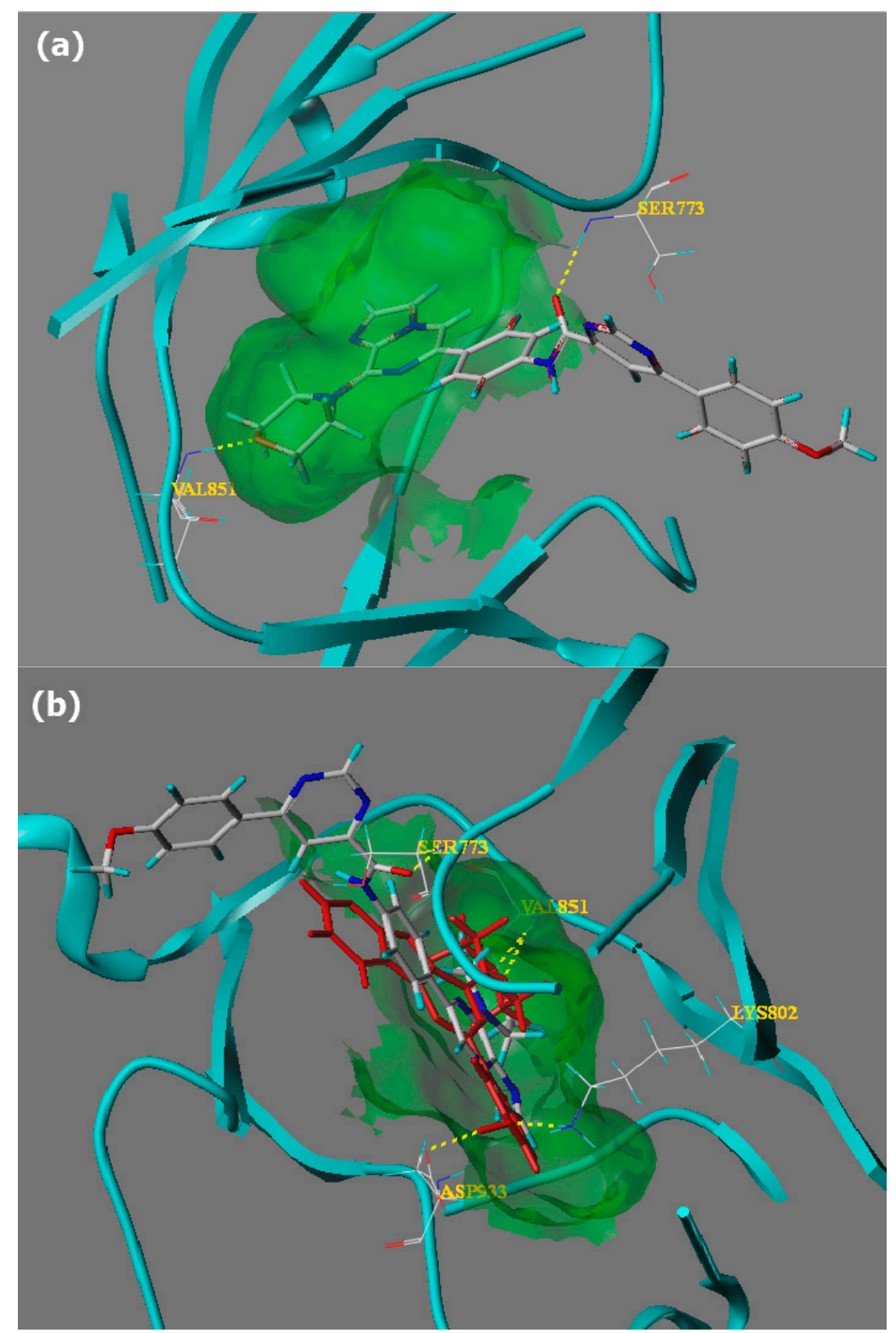

Figure 2. Binding models: The proteins were displayed by cyan ribbon. Hydrogen bonds were showed in dashed lines (yellow). (a) Binding models of compound 14c (shown in Capped Sticks) with PI3K $\alpha$; (b) Binding models of compound 14c and native ligand PI 103 (shown in red Sticks) with PI3K $\alpha$.

\section{Experimental Section}

\subsection{General Information}

All melting points were obtained on a Büchi Melting Point B-540 apparatus (Büchi Labortechnik, Flawil, Switzerland). NMR spectra were recorded using a Bruker $400 \mathrm{MHz}$ spectrometer (Bruker Bioscience, Billerica, MA, USA) with TMS as an internal standard. Mass spectra (MS) were taken in ESI mode on Agilent 1100 LC-MS (Agilent, Palo Alto, CA, USA). TLC analysis was carried out on silica gel plates GF254 (Qingdao Haiyang Chemical, Qingdao, China). All the reagents were obtained from commercial suppliers and used without purification, unless otherwise specified. 


\subsection{Chemistry}

\section{3,5-Dibromo-2-aminopyrazine (1)}

A solution of dichloromethane $(200 \mathrm{~mL})$ and pyridine $(25.3 \mathrm{~mL}, 0.315 \mathrm{~mol})$ was added to a three-necked flask containing 2-aminopyrazine $(14.27 \mathrm{~g}, 0.15 \mathrm{~mol})$ and stirred well. In the dark and while refluxing a solution of bromine $(16.2 \mathrm{~mL}, 0.315 \mathrm{~mol})$ in dichloromethane $(100 \mathrm{~mL})$ was slowly added dropwise to the three-necked flask. About $1 \mathrm{~h}$ later the addition finished and the mixture was refluxed at $40{ }^{\circ} \mathrm{C}$ for $30 \mathrm{~min}$ more. After TLC monitoring indicated the reaction was complete, the reaction mixture was cooled to room temperature and distilled water $(50 \mathrm{~mL})$ was added and the mixture was stirred vigorously for $10 \mathrm{~min}$. Then the organic layer was collected and washed twice with distilled water. Silica gel $(10 \mathrm{~g})$ and activated carbon $(1 \mathrm{~g})$ were added to the organic layer and the mixture was decolorized under reflux for $30 \mathrm{~min}$. After hot filtration, the filtrate was collected and vacuum distilled. The residue was refluxed with $n$-hexane $(45 \mathrm{~mL})$ for $2 \mathrm{~h}$, filtered while hot again and the solid product was dried and weighed to give $18.15 \mathrm{~g}$ of a pale yellow solid (47.8\% yield). ${ }^{1} \mathrm{H}-\mathrm{NMR}$ $\left(\mathrm{DMSO}_{-} d_{6}\right) \delta 8.14(\mathrm{~s}, 1 \mathrm{H}), 7.01(\mathrm{~s}, 2 \mathrm{H})$.

\section{3-Morpholino-5-bromo-2-aminopyrazine (2)}

A mixture of morpholine $(50 \mathrm{~mL})$ and 3,5-dibromo-2-aminopyrazine ( $12.50 \mathrm{~g})$ was refluxed for $1 \mathrm{~h}$ until the reaction was complete by TLC analysis. The solution was cooled to room temperature and added to a beaker containing ice water $(300 \mathrm{~mL})$ with continuous stirring. The solid was precipitated and filtered. After drying, $12.30 \mathrm{~g}$ of a yellow solid with a metallic luster was obtained (a yield of 96.1\%). ${ }^{1} \mathrm{H}-\mathrm{NMR}$ (DMSO- $\left.d_{6}\right) \delta 7.70(\mathrm{~s}, 1 \mathrm{H}), 6.28(\mathrm{~s}, 2 \mathrm{H}), 3.85-3.62(\mathrm{~m}, 4 \mathrm{H}), 3.04(\mathrm{~d}, J=4.0 \mathrm{~Hz}, 4 \mathrm{H})$.

\section{4-(6-Bromoimidazo[1,2-a]pyrazin-8-yl)morpholine (3)}

Chloroacetaldehyde $(4.4 \mathrm{~g})$ was mixed with isopropanol $(15 \mathrm{~mL})$ and a portion of the mixture $(10 \mathrm{~mL})$ was added to a round bottom flask containing compound $2(1.7 \mathrm{~g})$. Then the temperature was raised to $45^{\circ} \mathrm{C}$ and stirring was continued. After $1 \mathrm{~h}$, the remaining solution was added and the temperature raised to $65^{\circ} \mathrm{C}$ with continuous stirring. After TLC indicated the reaction was finished, the reaction was stopped and cooled to room temperature. Then the solution was added into a beaker containing ice water $(300 \mathrm{~mL})$ with continuous stirring. The brown-yellow solid that precipitated was filtered and dried to give the product in a yield of $26.8 \% .{ }^{1} \mathrm{H}-\mathrm{NMR}$ (DMSO- $\left.d_{6}\right) \delta 7.93(\mathrm{~s}, 1 \mathrm{H})$, $7.25(\mathrm{~d}, J=7.3 \mathrm{~Hz}, 1 \mathrm{H}), 7.01(\mathrm{~d}, J=7.3 \mathrm{~Hz}, 1 \mathrm{H}), 3.45(\mathrm{~s}, 4 \mathrm{H}), 3.77(\mathrm{~d}, J=4.3 \mathrm{~Hz}, 4 \mathrm{H})$.

\section{4-(6-(4-Nitrophenyl)imidazo[1,2-a]pyrazin-8-yl)morpholine (4)}

Compound 4 was prepared using the synthetic method described in our previous article [11]. Briefly, a solution of 1-bromo-4-nitrobenzene ( $2 \mathrm{~g}, 0.01 \mathrm{~mol})$, bis(pinacolato) diboron ( $3.8 \mathrm{~g}, 0.015 \mathrm{~mol})$, potassiumacetate $(2.9 \mathrm{~g}, 0.03 \mathrm{~mol})$ and bistriphenylphosphine palladium dichloride $(0.18 \mathrm{~g}, 0.25 \mathrm{mmol})$ was added to 1,4-dioxane $(50 \mathrm{~mL})$ and heated to $80^{\circ} \mathrm{C}$. The reaction was continued for $3 \mathrm{~h}$ under $\mathrm{N}_{2}$ and monitored by TLC. $\mathrm{H}_{2} \mathrm{O}(20 \mathrm{~mL})$ was added to the solution and continued for $5 \mathrm{~min}$. Subsequently, compound 3 ( $1.7 \mathrm{~g}, 0.006 \mathrm{~mol}), \mathrm{Na}_{2} \mathrm{CO}_{3}(2.1 \mathrm{~g}, 0.02 \mathrm{~mol})$ and bistriphenylphosphine dichloride $(0.18 \mathrm{~g}$, $0.25 \mathrm{mmol}$ ) were added successively, then the mixture was heated to $100{ }^{\circ} \mathrm{C}$. The reaction was continued for about $8 \mathrm{~h}$. The mixture was cooled and concentrated under vacuum. $\mathrm{H}_{2} \mathrm{O}(100 \mathrm{~mL})$ was added, stirred for $30 \mathrm{~min}$ and then filtered. The filter cake was decolorized with activated carbon $(5 \mathrm{~g})$ and silica gel $(2 \mathrm{~g})$ in a mixed solvent $\left(\mathrm{CH}_{2} \mathrm{Cl}_{2}: \mathrm{CH}_{3} \mathrm{OH}=5: 1,100 \mathrm{~mL}\right)$, filtered while hot and concentrated under vacuum to obtain 4 with a yield of $63.0 \%$. ESI-MS $m / z$ : $[\mathrm{M}+\mathrm{H}]^{+} 326.1$. ${ }^{1} \mathrm{H}-\mathrm{NMR}\left(\mathrm{DMSO}-d_{6}\right) \delta$ $8.78(\mathrm{~d}, J=8.2 \mathrm{~Hz} 2 \mathrm{H}), 8.33(\mathrm{~d}, J=8.2 \mathrm{~Hz} 2 \mathrm{H}), 8.01(\mathrm{~s}, 1 \mathrm{H}), 7.20(\mathrm{~d}, J=8.7 \mathrm{~Hz}, 1 \mathrm{H}), 6.95(\mathrm{~d}, J=8.7 \mathrm{~Hz}$, $1 \mathrm{H}), 3.91(\mathrm{~s}, 4 \mathrm{H}), 3.77(\mathrm{~s}, 4 \mathrm{H})$. 
4-(8-Morpholinoimidazo[1,2-a]pyridin-6-yl)aniline (5)

The synthesis of compound 5 is similar to the synthetic method reported in our previous article [11]. Compound $4(3.3 \mathrm{~g}, 0.01 \mathrm{~mol})$ was refluxed with hydrazine hydrate $(5 \mathrm{~g}, 0.1 \mathrm{~mol})$, ferric chloride $(0.5 \mathrm{~g}, 0.002 \mathrm{~mol})$ and an appropriate amount of activated carbon in ethanol $(50 \mathrm{~mL})$ for $30 \mathrm{~min}-1 \mathrm{~h}$ and monitored by TLC. After filtering while hot and concentrating under vacuum compound 5 was obtain in a yield of $60.2 \%$. ESI-MS $m / z:[\mathrm{M}+\mathrm{H}]^{+}$296.2. $[\mathrm{M}+\mathrm{H}]^{+}$326.1. ${ }^{1} \mathrm{H}-\mathrm{NMR}$ $\left(\right.$ DMSO- $\left.d_{6}\right) \delta 8.12(\mathrm{~d}, J=8.5 \mathrm{~Hz} 2 \mathrm{H}), 7.89(\mathrm{~s}, 1 \mathrm{H}), 7.12(\mathrm{~d}, J=8.3 \mathrm{~Hz}, 1 \mathrm{H}), 6.99(\mathrm{~d}, J=8.3 \mathrm{~Hz}, 1 \mathrm{H})$, $6.60(\mathrm{~d}, J=8.5 \mathrm{~Hz} 2 \mathrm{H}), 5.56(\mathrm{~s}, 2 \mathrm{H}), 3.75(\mathrm{~d}, J=3.5 \mathrm{~Hz}, 4 \mathrm{H}), 3.32(\mathrm{~s}, 4 \mathrm{H})$.

\section{General Procedure for the Preparation of Compounds $\mathbf{6 a}-\mathbf{g}, \mathbf{7 a}-\mathbf{g}, \mathbf{8 a}-\mathbf{g}, \mathbf{9 a}-\mathbf{g}, \mathbf{1 0 a}-\mathbf{g}$ and $\mathbf{1 1 a}-\mathbf{g}$}

Compounds $6 \mathbf{a}-\mathbf{g}, 7 \mathbf{a}-\mathbf{g}$ and $8 \mathbf{a}-\mathbf{g}$ were synthesized according to the procedures reported by our research group [11,12]. Then compounds $6 \mathbf{a}-\mathbf{g}, 7 \mathbf{a}-\mathbf{g}$ and $8 \mathbf{a}-\mathbf{g}(0.02 \mathrm{mmol})$ were dissolved in thionyl chloride $(8 \mathrm{~mL})$ and refluxed for $1 \mathrm{~h}$. The reaction mixture was evaporated to yield the corresponding chloride which was dissolved in dichloromethane $(10 \mathrm{~mL})$. The solution of $\mathbf{9 a}-\mathbf{g}, \mathbf{1 0 a}-\mathbf{g}$ or 11a-g was used for the next step without further purification.

\section{General Procedure for the Preparation of the Target Compounds 12a-g, 13a-g and 14a-g}

A solution of phenylpyrimidine chloride $\mathbf{9 a}-\mathbf{g}, \mathbf{1 0 a}-\mathbf{g}$ or $\mathbf{1 1 a}-\mathbf{g}$ in dichloromethane $(10 \mathrm{~mL})$ was added dropwise to a solution of $5(0.12 \mathrm{~mol})$ and $N, N$-diisopropylethylamine $(0.048 \mathrm{~mol})$ in dichloromethane $(10 \mathrm{~mL})$ in an ice bath. Upon completion of the addition, the reaction mixture was removed from the ice bath, held at room temperature for $15 \mathrm{~min}$ and monitored by thin-layer chromatography (TLC). The mixture was washed with $10 \% \mathrm{~K}_{2} \mathrm{CO}_{3}(50 \mathrm{~mL} \times 3)$ followed by brine $(50 \mathrm{~mL} \times 1)$, and the organic layer was separated, dried over anhydrous sodium sulfate, and evaporated to yield the target compounds $12 \mathbf{a}-\mathbf{g}, 13 \mathbf{a}-\mathbf{g}$ and $\mathbf{1 4 a}-\mathbf{g}$ which were recrystallized from isopropanol. In addition, all the target compounds were purified by silica gel column chromatography $\left(\mathrm{CH}_{2} \mathrm{Cl}_{2}: \mathrm{CH}_{3} \mathrm{OH}=100: 1\right)$.

N-(4-Morpholinoimidazo[1,2-a]pyridin-6-yl) phenyl)-4-phenylpyridine amide (12a). A yellow solid; yield: 96.1\%; m.p. 268-270 ${ }^{\circ} \mathrm{C}$; ESI-MS [M + H] ${ }^{+} m / z: 477.2 ;{ }^{1} \mathrm{H}-\mathrm{NMR}\left(\mathrm{CDCl}_{3}\right) \delta 10.46(\mathrm{~s}, 1 \mathrm{H}), 9.06(\mathrm{~s}, 1 \mathrm{H})$, $8.86(\mathrm{~s}, 2 \mathrm{H}), 8.39(\mathrm{~d}, J=8.0 \mathrm{~Hz}, 1 \mathrm{H}), 8.28(\mathrm{~d}, J=8.1 \mathrm{~Hz}, 1 \mathrm{H}), 8.22(\mathrm{~d}, J=8.2 \mathrm{~Hz}, 1 \mathrm{H}), 8.13-8.04(\mathrm{~m}, 4 \mathrm{H})$, $7.96(\mathrm{~s}, 3 \mathrm{H}), 7.83(\mathrm{~s}, 2 \mathrm{H}), 4.21(\mathrm{~s}, 4 \mathrm{H}), 4.01(\mathrm{~s}, 4 \mathrm{H})$.

5-(3-Fluorophenyl)-N-(4-(8-morpholinoimidazo[1,2-a]pyrazin-6-yl)phenyl)picolinamide (12b). A yellow solid; yield: 79.4\%; m.p. 261-264 ${ }^{\circ} \mathrm{C}$; ESI-MS [M + H] ${ }^{+} \mathrm{m} / z: 495.2 ;{ }^{1} \mathrm{H}-\mathrm{NMR}\left(400 \mathrm{MHz}, \mathrm{CDCl}_{3}\right) \delta 10.18(\mathrm{~s}, 1 \mathrm{H})$, $8.85(\mathrm{~s}, 2 \mathrm{H}), 8.40(\mathrm{~d}, J=8.1 \mathrm{~Hz}, 2 \mathrm{H}), 8.29(\mathrm{~d}, J=8.1 \mathrm{~Hz}, 1 \mathrm{H}), 8.09(\mathrm{~s}, 3 \mathrm{H}), 7.88(\mathrm{~s}, 1 \mathrm{H}), 7.75(\mathrm{~s}, 1 \mathrm{H}), 7.52(\mathrm{~d}$, $J=5.1 \mathrm{~Hz}, 1 \mathrm{H}), 7.45(\mathrm{~s}, 1 \mathrm{H}), 7.36(\mathrm{~d}, J=9.2 \mathrm{~Hz}, 1 \mathrm{H}), 7.20(\mathrm{~d}, J=9.0 \mathrm{~Hz}, 1 \mathrm{H}), 4.17(\mathrm{~s}, 4 \mathrm{H}), 4.03(\mathrm{~s}, 4 \mathrm{H})$.

5-(2,4-Difluorophenyl)-N-(4-(8-morpholinoimidazo[1,2-a]pyrazin-6-yl)phenyl)picolinamide (12c). A pale yellow solid; yield: $90.2 \%$; m.p. $255-257{ }^{\circ} \mathrm{C}$; ESI-MS $[\mathrm{M}+\mathrm{H}]^{+} \mathrm{m} / z: 513.2 ;{ }^{1} \mathrm{H}-\mathrm{NMR}\left(\mathrm{DMSO}-\mathrm{d}_{6}\right) \delta$ 10.97-10.71 (m, 1H), $8.86(\mathrm{~s}, 1 \mathrm{H}), 8.35(\mathrm{~d}, J=9.2 \mathrm{~Hz}, 1 \mathrm{H}), 8.22(\mathrm{~s}, 1 \mathrm{H}), 8.04(\mathrm{~s}, 1 \mathrm{H}), 7.84-7.71(\mathrm{~m}, 1 \mathrm{H})$, $7.60(\mathrm{~d}, J=12.2 \mathrm{~Hz}, 2 \mathrm{H}), 7.51-7.37(\mathrm{~m}, 1 \mathrm{H}), 7.32-7.17(\mathrm{~m}, 1 \mathrm{H}), 6.51(\mathrm{~s}, 2 \mathrm{H}), 6.30(\mathrm{~s}, 2 \mathrm{H}), 3.92(\mathrm{~s}, 4 \mathrm{H})$, $3.74(\mathrm{~s}, 4 \mathrm{H})$.

$\mathrm{N}$-(4-(8-Morpholinoimidazo[1,2-a]pyrazin-6-yl)phenyl)-5-(4-(trifluoromethyl)phenyl)picolinamide (12d). A gray solid; yield: 83.5\%; m.p. $233-235{ }^{\circ} \mathrm{C}$; ESI-MS $[\mathrm{M}+\mathrm{H}]^{+} \mathrm{m} / z: 545.2 ;{ }^{1} \mathrm{H}-\mathrm{NMR}\left(\mathrm{CDCl}_{3}\right) \delta 10.46$ $(\mathrm{s}, 1 \mathrm{H}), 8.88(\mathrm{~s}, 2 \mathrm{H}), 8.33(\mathrm{~d}, J=8.0 \mathrm{~Hz}, 2 \mathrm{H}), 8.23(\mathrm{~d}, J=14.9 \mathrm{~Hz}, 1 \mathrm{H}), 8.12(\mathrm{~s}, 2 \mathrm{H}), 7.99(\mathrm{~d}, J=22.6 \mathrm{~Hz}$, $5 \mathrm{H}), 7.56(\mathrm{~s}, 1 \mathrm{H}), 7.48(\mathrm{~s}, 1 \mathrm{H}), 4.08(\mathrm{~d}, J=18.4 \mathrm{~Hz}, 8 \mathrm{H}) .{ }^{13} \mathrm{C}-\mathrm{NMR}\left(\mathrm{DMSO}-d_{6}\right) \delta 162.66,157.43,149.99$, $147.87,147.28,138.75,137.36,136.99,136.53,135.92,132.97,132.96,132.52,132.29,128.69$ (2C), $128.68(2 \mathrm{C}), 128.52,126.28(2 \mathrm{C}), 123.14,120.76(2 \mathrm{C}), 116.11,66.73(2 \mathrm{C}), 46.71(2 \mathrm{C})$.

5-(4-Methoxyphenyl)-N-(4-(8-morpholinoimidazo[1,2-a]pyrazin-6-yl)phenyl)picolinamide (12e). A pale yellow solid; yield: 93.3\%; m.p. $255-257{ }^{\circ} \mathrm{C}$; ESI-MS $[\mathrm{M}+\mathrm{H}]^{+} \mathrm{m} / z: 507.2 ;{ }^{1} \mathrm{H}-\mathrm{NMR}$ (DMSO- $d_{6}$ ) 
$\delta 11.05(\mathrm{~s}, 1 \mathrm{H}), 8.74(\mathrm{~d}, J=5.1 \mathrm{~Hz}, 1 \mathrm{H}), 8.57(\mathrm{~s}, 1 \mathrm{H}), 8.47(\mathrm{~s}, 1 \mathrm{H}), 8.03(\mathrm{~d}, J=8.6 \mathrm{~Hz}, 2 \mathrm{H}), 8.02(\mathrm{~s}, 2 \mathrm{H})$, $7.87(\mathrm{~d}, J=9.8 \mathrm{~Hz}, 2 \mathrm{H}), 7.86(\mathrm{~d}, J=8.6 \mathrm{~Hz}, 2 \mathrm{H}), 7.51(\mathrm{~s}, 1 \mathrm{H}), 7.14(\mathrm{~d}, J=8.6 \mathrm{~Hz}, 2 \mathrm{H}), 4.32(\mathrm{~s}, 4 \mathrm{H})$, $4.19(\mathrm{~s}, 2 \mathrm{H}), 3.85(\mathrm{~d}, J=3.9 \mathrm{~Hz}, 3 \mathrm{H})$.

N-(4-(8-Morpholinoimidazo[1,2-a]pyrazin-6-yl)phenyl)-5-(m-tolyl)picolinamide (12f). A pale yellow solid; yield: 72.6\%; m.p. $241-243{ }^{\circ} \mathrm{C}$; ESI-MS $[\mathrm{M}+\mathrm{H}]^{+} \mathrm{m} / z: 491.2 ;{ }^{1} \mathrm{H}-\mathrm{NMR}\left(\mathrm{CDCl}_{3}\right) \delta 10.17(\mathrm{~s}, 1 \mathrm{H})$, $8.84(\mathrm{~s}, 1 \mathrm{H}), 8.36(\mathrm{~d}, J=8.0 \mathrm{~Hz}, 1 \mathrm{H}), 8.30-8.22(\mathrm{~m}, 1 \mathrm{H}), 8.20(\mathrm{~d}, J=7.5 \mathrm{~Hz}, 1 \mathrm{H}), 8.10(\mathrm{~d}, J=9.8 \mathrm{~Hz}, 2 \mathrm{H})$, $8.06(\mathrm{~s}, 2 \mathrm{H}), 7.93(\mathrm{~d}, J=8.2 \mathrm{~Hz}, 2 \mathrm{H}), 7.74(\mathrm{~s}, 1 \mathrm{H}), 7.56(\mathrm{~d}, J=7.3 \mathrm{~Hz}, 3 \mathrm{H}), 4.25(\mathrm{~s}, 4 \mathrm{H}), 3.98(\mathrm{~s}, 4 \mathrm{H})$, $2.44(\mathrm{~s}, 3 \mathrm{H})$.

$\mathrm{N}$-(4-(8-Morpholinoimidazo[1,2-a]pyrazin-6-yl)phenyl)-5-(p-tolyl)picolinamide (12g). A pale yellow solid; yield: 89.1\%; m.p. $258-260{ }^{\circ} \mathrm{C}$; ESI-MS [M + H] ${ }^{+} m / z: 491.2 ;{ }^{1} \mathrm{H}-\mathrm{NMR}\left(\mathrm{DMSO}-\mathrm{d}_{6}\right) \delta 10.79(\mathrm{~s}, 1 \mathrm{H})$, $9.02(\mathrm{~d}, J=9.4 \mathrm{~Hz}, 2 \mathrm{H}), 8.59(\mathrm{~s}, 1 \mathrm{H}), 8.35(\mathrm{~d}, J=8.1 \mathrm{~Hz}, 1 \mathrm{H}), 8.24(\mathrm{~d}, J=8.1 \mathrm{~Hz}, 1 \mathrm{H}), 8.05(\mathrm{~d}, J=8.7 \mathrm{~Hz}$, 2H), $7.77(\mathrm{~s}, 2 \mathrm{H}), 7.59(\mathrm{~s}, 2 \mathrm{H}), 7.37(\mathrm{t}, J=8.5 \mathrm{~Hz}, 3 \mathrm{H}), 4.30(\mathrm{~s}, 4 \mathrm{H}), 3.80(\mathrm{~s}, 4 \mathrm{H}), 2.40(\mathrm{~s}, 3 \mathrm{H})$.

N-(4-(8-Morpholinoimidazo[1,2-a]pyrazin-6-yl)phenyl)-4-phenylpicolinamide (13a). A yellow solid; yield: 97.0\%; m.p. $261-262{ }^{\circ} \mathrm{C}$; ESI-MS [M + H] ${ }^{+} m / z:$ 477.2; ${ }^{1} \mathrm{H}-\mathrm{NMR}$ (DMSO- $\left.d_{6}\right) \delta 9.55(\mathrm{~s}, 1 \mathrm{H})$, $7.59(\mathrm{~d}, J=5.0 \mathrm{~Hz}, 1 \mathrm{H}), 7.34(\mathrm{~s}, 1 \mathrm{H}), 7.20(\mathrm{~s}, 1 \mathrm{H}), 6.79(\mathrm{~d}, J=7.8 \mathrm{~Hz}, 5 \mathrm{H}), 6.74-6.65(\mathrm{~m}, 3 \mathrm{H}), 6.34$ $(\mathrm{dd}, J=8.4,4.3 \mathrm{~Hz}, 4 \mathrm{H}), 3.07(\mathrm{~s}, 4 \mathrm{H}), 2.61-2.51(\mathrm{~m}, 4 \mathrm{H})$.

4-(3-Fluorophenyl)-N-(4-(8-morpholinoimidazo[1,2-a]pyrazin-6-yl)phenyl)picolinamide (13b). A white solid; yield: 88.0\%; m.p. $237-239{ }^{\circ} \mathrm{C}$; ESI-MS [M + H] ${ }^{+} m / z: 495.2 ;{ }^{1} \mathrm{H}-\mathrm{NMR}\left(\mathrm{DMSO}-\mathrm{d}_{6}\right) \delta 10.85(\mathrm{~s}, 1 \mathrm{H})$, $8.84(\mathrm{~d}, J=5.0 \mathrm{~Hz}, 1 \mathrm{H}), 8.80(\mathrm{~d}, J=5.0 \mathrm{~Hz}, 1 \mathrm{H}), 8.60(\mathrm{~s}, 1 \mathrm{H}), 8.45(\mathrm{~s}, 1 \mathrm{H}), 8.33(\mathrm{~s}, 1 \mathrm{H}), 8.06(\mathrm{dd}, J=5.7$, $3.5 \mathrm{~Hz}, 3 \mathrm{H}), 7.96(\mathrm{~s}, 1 \mathrm{H}), 7.85-7.79(\mathrm{~m}, 2 \mathrm{H}), 7.63(\mathrm{~d}, J=7.7 \mathrm{~Hz}, 1 \mathrm{H}), 7.45-7.33(\mathrm{~m}, 2 \mathrm{H}), 4.30(\mathrm{~s}, 4 \mathrm{H})$, $3.80(\mathrm{~d}, J=4.2 \mathrm{~Hz}, 4 \mathrm{H})$.

4-(2,4-Difluorophenyl)-N-(4-(8-morpholinoimidazo[1,2-a]pyrazin-6-yl)phenyl)picolinamide (13c). A pale yellow solid; yield: 91.2\%; m.p. $266-267{ }^{\circ} \mathrm{C}$; ESI-MS [M + H] ${ }^{+} \mathrm{m} / z: 513.2 ;{ }^{1} \mathrm{H}-\mathrm{NMR}$ (DMSO- $\left.d_{6}\right) \delta 10.76$ $(\mathrm{s}, 1 \mathrm{H}), 8.79(\mathrm{~d}, J=5.1 \mathrm{~Hz}, 1 \mathrm{H}), 8.52(\mathrm{~s}, 1 \mathrm{H}), 8.26(\mathrm{~s}, 1 \mathrm{H}), 7.96(\mathrm{~d}, J=7.3 \mathrm{~Hz}, 4 \mathrm{H}), 7.89(\mathrm{~s}, 1 \mathrm{H}), 7.85-7.74$ $(\mathrm{m}, 2 \mathrm{H}), 7.52(\mathrm{~s}, 1 \mathrm{H}), 7.43(\mathrm{~d}, J=9.6 \mathrm{~Hz}, 1 \mathrm{H}), 7.26(\mathrm{t}, J=8.3 \mathrm{~Hz}, 1 \mathrm{H}), 4.23(\mathrm{~s}, 4 \mathrm{H}), 3.74(\mathrm{~d}, J=4.3 \mathrm{~Hz}, 4 \mathrm{H})$.

$\mathrm{N}$-(4-(8-Morpholinoimidazo[1,2-a]pyrazin-6-yl)phenyl)-4-(4-(trifluoromethyl)phenyl)picolinamide (13d). A pale yellow solid; yield: $81.8 \%$; m.p. $269-272{ }^{\circ} \mathrm{C}$; ESI-MS [M + H] ${ }^{+} m / z: 545.2 ;{ }^{1} \mathrm{H}-\mathrm{NMR}\left(\mathrm{DMSO}-d_{6}\right.$ ) $\delta 10.86(\mathrm{~s}, 1 \mathrm{H}), 8.88(\mathrm{~d}, J=5.0 \mathrm{~Hz}, 1 \mathrm{H}), 8.59(\mathrm{~s}, 1 \mathrm{H}), 8.49(\mathrm{~s}, 1 \mathrm{H}), 8.15(\mathrm{~d}, J=8.0 \mathrm{~Hz}, 2 \mathrm{H}), 8.13-8.07$ $(\mathrm{m}, 2 \mathrm{H}), 8.03(\mathrm{~d}, J=11.5 \mathrm{~Hz}, 3 \mathrm{H}), 8.00(\mathrm{~s}, 1 \mathrm{H}), 7.95(\mathrm{~d}, J=8.4 \mathrm{~Hz}, 2 \mathrm{H}), 7.59(\mathrm{~s}, 1 \mathrm{H}), 4.30(\mathrm{~s}, 4 \mathrm{H})$, $3.80(\mathrm{~d}, J=4.0 \mathrm{~Hz}, 4 \mathrm{H})$.

4-(4-Methoxyphenyl)-N-(4-(8-morpholinoimidazo[1,2-a]pyrazin-6-yl)phenyl)picolinamide (13e). A pale yellow solid; yield: 93.1\%; m.p. $257-260{ }^{\circ} \mathrm{C}$; ESI-MS $[\mathrm{M}+\mathrm{H}]^{+} \mathrm{m} / z: 507.2 ;{ }^{1} \mathrm{H}-\mathrm{NMR}$ (DMSO- $d_{6}$ ) $\delta 10.82(\mathrm{~s}, 1 \mathrm{H}), 8.76(\mathrm{~d}, J=5.1 \mathrm{~Hz}, 1 \mathrm{H}), 8.60(\mathrm{~s}, 1 \mathrm{H}), 8.40(\mathrm{~s}, 1 \mathrm{H}), 8.05(\mathrm{~d}, J=8.6 \mathrm{~Hz}, 2 \mathrm{H}), 8.02(\mathrm{~s}, 2 \mathrm{H}), 7.97$ $(\mathrm{d}, J=9.8 \mathrm{~Hz}, 2 \mathrm{H}), 7.91(\mathrm{~d}, J=8.6 \mathrm{~Hz}, 2 \mathrm{H}), 7.59(\mathrm{~s}, 1 \mathrm{H}), 7.14(\mathrm{~d}, J=8.6 \mathrm{~Hz}, 2 \mathrm{H}), 4.30(\mathrm{~s}, 4 \mathrm{H}), 3.85(\mathrm{~s}, 2 \mathrm{H})$, $3.80(\mathrm{~d}, J=3.9 \mathrm{~Hz}, 3 \mathrm{H})$.

$N$-(4-(8-Morpholinoimidazo[1,2-a]pyrazin-6-yl)phenyl)-4-(m-tolyl)picolinamide (13f). A pale red solid; yield: 91.5\%; m.p. $233-234{ }^{\circ} \mathrm{C}$; ESI-MS [M + H] ${ }^{+} m / z: 491.2 ;{ }^{1} \mathrm{H}-\mathrm{NMR}$ (DMSO- $\left.d_{6}\right) \delta 10.82(\mathrm{~s}, 1 \mathrm{H}$ ), $8.79(\mathrm{~d}, J=4.9 \mathrm{~Hz}, 1 \mathrm{H}), 8.59(\mathrm{~s}, 1 \mathrm{H}), 8.42(\mathrm{~s}, 1 \mathrm{H}), 8.30(\mathrm{~s}, 1 \mathrm{H}), 8.05(\mathrm{~d}, J=8.4 \mathrm{~Hz}, 3 \mathrm{H}), 7.83(\mathrm{~d}, J=8.1 \mathrm{~Hz}$, $3 \mathrm{H}), 7.59(\mathrm{~s}, 1 \mathrm{H}), 7.43-7.36(\mathrm{~m}, 3 \mathrm{H}), 4.30(\mathrm{~s}, 4 \mathrm{H}), 3.80(\mathrm{~d}, J=3.7 \mathrm{~Hz}, 4 \mathrm{H}), 2.40(\mathrm{~s}, 3 \mathrm{H})$.

$\mathrm{N}$-(4-(8-Morpholinoimidazo[1,2-a]pyrazin-6-yl)phenyl)-4-(p-tolyl)picolinamide (13g). A brown solid; yield: 98.0\%; m.p. $271-273{ }^{\circ} \mathrm{C}$; ESI-MS [M + H]+ m/z: 491.2; ${ }^{1} \mathrm{H}-\mathrm{NMR}$ (DMSO- $\left.d_{6}\right) \delta 9.87(\mathrm{~s}, 1 \mathrm{H})$, $7.90(\mathrm{~d}, J=5.2 \mathrm{~Hz}, 1 \mathrm{H}), 7.56(\mathrm{~s}, 1 \mathrm{H}), 7.44(\mathrm{~s}, 1 \mathrm{H}), 7.22-7.15(\mathrm{~m}, 3 \mathrm{H}), 6.95(\mathrm{~d}, J=8.5 \mathrm{~Hz}, 3 \mathrm{H}), 6.73(\mathrm{~s}, 1 \mathrm{H})$, $6.54(\mathrm{~s}, 4 \mathrm{H}), 3.45(\mathrm{~s}, 4 \mathrm{H}), 3.15-2.68(\mathrm{~m}, 4 \mathrm{H}), 2.33(\mathrm{~s}, 3 \mathrm{H}) .{ }^{13} \mathrm{C}-\mathrm{NMR}$ (DMSO-d 6 ) $\delta$ 162.98, 151.15, 149.90, $149.64,149.31,147.87,140.08,138.78,135.91,134.03,132.94,132.30,130.48$ (2C), 127.35 (2C), 127.31, 126.29 (2C), 120.70, $119.64(2 \mathrm{C}), 116.13,116.11,66.73(2 \mathrm{C}), 46.70(2 \mathrm{C}), 21.29$. 
N-(4-(8-Morpholinoimidazo[1,2-a]pyrazin-6-yl)phenyl)-6-phenylpyrimidine-4-carboxamide (14a). A pale yellow solid; yield: 82.7\%; m.p. $272-275{ }^{\circ} \mathrm{C}$; ESI-MS $[\mathrm{M}+\mathrm{H}]^{+} \mathrm{m} / z: 478.1 ;{ }^{1} \mathrm{H}-\mathrm{NMR}\left(\mathrm{DMSO}-d_{6}\right) \delta 10.79$ $(\mathrm{s}, 1 \mathrm{H}), 8.75(\mathrm{~d}, J=5.1 \mathrm{~Hz}, 1 \mathrm{H}), 8.58(\mathrm{~s}, 1 \mathrm{H}), 8.39(\mathrm{~s}, 1 \mathrm{H}), 8.04(\mathrm{~d}, J=8.7 \mathrm{~Hz}, 2 \mathrm{H}), 8.01(\mathrm{~s}, 1 \mathrm{H}), 7.98(\mathrm{~d}, J=$ $6.3 \mathrm{~Hz}, 2 \mathrm{H}), 7.95(\mathrm{~s}, 1 \mathrm{H}), 7.89(\mathrm{~d}, J=8.5 \mathrm{~Hz}, 2 \mathrm{H}), 7.58(\mathrm{~s}, 1 \mathrm{H}), 7.13(\mathrm{~d}, J=8.5 \mathrm{~Hz}, 2 \mathrm{H}), 4.29(\mathrm{~s}, 4 \mathrm{H}), 3.80$ $(\mathrm{d}, J=4.3 \mathrm{~Hz}, 4 \mathrm{H})$.

N-(4-(8-Morpholinoimidazo[1,2-a]pyrazin-6-yl)phenyl)-6-(p-tolyl)pyrimidine-4-carboxamide (14b). A pale yellow solid; yield: 79.5\%; m.p. $222-225{ }^{\circ} \mathrm{C}$; ESI-MS $[\mathrm{M}+\mathrm{H}]^{+} m / z: 492.2 ;{ }^{1} \mathrm{H}-\mathrm{NMR}\left(\mathrm{DMSO}-d_{6}\right) \delta$ $10.82(\mathrm{~s}, 1 \mathrm{H}), 8.77(\mathrm{dd}, J=22.5,5.1 \mathrm{~Hz}, 2 \mathrm{H}), 8.58(\mathrm{~s}, 1 \mathrm{H}), 8.41(\mathrm{~s}, 1 \mathrm{H}), 8.27(\mathrm{~s}, 1 \mathrm{H}), 7.94-7.87(\mathrm{~m}, 2 \mathrm{H})$, $7.58(\mathrm{~s}, 2 \mathrm{H}), 7.41(\mathrm{t}, J=8.3 \mathrm{~Hz}, 4 \mathrm{H}), 4.29(\mathrm{~s}, 4 \mathrm{H}), 3.79(\mathrm{~s}, 4 \mathrm{H}), 1.25(\mathrm{~d}, J=6.5 \mathrm{~Hz}, 3 \mathrm{H})$.

6-(4-Methoxyphenyl)-N-(4-(8-morpholinoimidazo[1,2-a]pyrazin-6-yl)phenyl)pyrimidine-4-carboxamide (14c). A pale brown solid; yield: 77.8\%; m.p. $269-271{ }^{\circ} \mathrm{C}$; ESI-MS [M + H] ${ }^{+} m / z: 508.2 ;{ }^{1} \mathrm{H}-\mathrm{NMR}\left(\mathrm{DMSO}-d_{6}\right)$ $\delta 10.96(\mathrm{~s}, 1 \mathrm{H}), 9.38(\mathrm{~s}, 1 \mathrm{H}), 8.57(\mathrm{~s}, 1 \mathrm{H}), 8.32(\mathrm{~d}, J=8.0 \mathrm{~Hz}, 2 \mathrm{H}), 8.03(\mathrm{dd}, J=14.7,8.4 \mathrm{~Hz}, 4 \mathrm{H})$, $7.96(\mathrm{~s}, 1 \mathrm{H}), 7.08(\mathrm{~d}, J=1.7 \mathrm{~Hz}, 2 \mathrm{H}), 7.05(\mathrm{~d}, J=1.6 \mathrm{~Hz}, 2 \mathrm{H}), 4.29(\mathrm{~s}, 4 \mathrm{H}), 3.87(\mathrm{~s}, 3 \mathrm{H}), 3.80(\mathrm{~s}, 4 \mathrm{H})$. ${ }^{13}$ C-NMR (DMSO- $\left.d_{6}\right) \delta$ 162.80, 162.53, 162.06, 158.73, 158.48, 157.98, 157.00, 138.37, 133.36, 132.96, $132.29,129.59$ (2C), 128.25, 128.20, 126.30 (2C), 120.98 (2C), 116.12, 114.98 (3C), 66.73 (2C), 55.95, $46.70(2 \mathrm{C})$.

6-(4-Bromophenyl)-N-(4-(8-morpholinoimidazo[1,2-a]pyrazin-6-yl)phenyl)pyrimidine-4-carboxamide (14d). A white solid; yield: 90.9\%; m.p. 221-223 ${ }^{\circ} \mathrm{C}$; ESI-MS [M + H] ${ }^{+} m / z: 557.1 ;{ }^{1} \mathrm{H}-\mathrm{NMR}\left(\mathrm{DMSO}-d_{6}\right) \delta 10.91$ $(\mathrm{s}, 1 \mathrm{H}), 9.49(\mathrm{~s}, 1 \mathrm{H}), 8.65(\mathrm{~s}, 1 \mathrm{H}), 8.59(\mathrm{~d}, J=11.9 \mathrm{~Hz}, 2 \mathrm{H}), 8.38(\mathrm{~d}, J=8.3 \mathrm{~Hz}, 2 \mathrm{H}), 8.00-7.94(\mathrm{~m}, 3 \mathrm{H})$, $7.85(\mathrm{~d}, J=8.3 \mathrm{~Hz}, 2 \mathrm{H}), 7.59(\mathrm{~d}, J=2.7 \mathrm{~Hz}, 2 \mathrm{H}), 4.30(\mathrm{~s}, 4 \mathrm{H}), 3.79(\mathrm{~d}, J=4.0 \mathrm{~Hz}, 4 \mathrm{H})$.

6-(4-Chlorophenyl)-N-(4-(8-morpholinoimidazo[1,2-a]pyrazin-6-yl)phenyl)pyrimidine-4-carboxamide (14e). A pale yellow solid; yield: 93.2\%; m.p. $235-237{ }^{\circ} \mathrm{C}$; ESI-MS $[\mathrm{M}+\mathrm{H}]^{+} \mathrm{m} / z: 513 . \quad 1 ;{ }^{1} \mathrm{H}-\mathrm{NMR}$ $\left(\mathrm{DMSO}-\mathrm{d}_{6}\right) \delta 10.81(\mathrm{~s}, 1 \mathrm{H}), 8.78(\mathrm{~d}, J=5.1 \mathrm{~Hz}, 1 \mathrm{H}), 8.58(\mathrm{~s}, 1 \mathrm{H}), 8.41(\mathrm{~s}, 1 \mathrm{H}), 8.05(\mathrm{~d}, J=8.8 \mathrm{~Hz}$, $2 \mathrm{H}), 8.00(\mathrm{~d}, J=7.5 \mathrm{~Hz}, 2 \mathrm{H}), 7.95(\mathrm{~s}, 1 \mathrm{H}), 7.83(\mathrm{~d}, J=8.0 \mathrm{~Hz}, 2 \mathrm{H}), 7.58(\mathrm{~s}, 1 \mathrm{H}), 7.41(\mathrm{~d}, J=8.0 \mathrm{~Hz}, 2 \mathrm{H})$, $4.29(\mathrm{~s}, 4 \mathrm{H}), 3.88-3.67(\mathrm{~m}, 4 \mathrm{H})$.

6-(4-Fluorophenyl)-N-(4-(8-morpholinoimidazo[1,2-a]pyrazin-6-yl)phenyl)pyrimidine-4-carboxamide (14f). A gray solid; yield: 80.8\%; m.p. $259-260{ }^{\circ} \mathrm{C}$; ESI-MS $[\mathrm{M}+\mathrm{H}]^{+} \mathrm{m} / z: 496.2 ;{ }^{1} \mathrm{H}-\mathrm{NMR}\left(\mathrm{CDCl}_{3}\right) \delta$ $10.05(\mathrm{~s}, 1 \mathrm{H}), 9.33(\mathrm{~s}, 1 \mathrm{H}), 8.97(\mathrm{~s}, 1 \mathrm{H}), 8.63(\mathrm{~s}, 1 \mathrm{H}), 8.17(\mathrm{dd}, J=18.2,8.6 \mathrm{~Hz}, 2 \mathrm{H}), 8.10-7.83(\mathrm{~m}, 5 \mathrm{H})$, $7.75(\mathrm{~d}, J=5.2 \mathrm{~Hz}, 1 \mathrm{H}), 7.55(\mathrm{~d}, J=8.0 \mathrm{~Hz}, 2 \mathrm{H}), 4.32(\mathrm{~s}, 4 \mathrm{H}), 3.96(\mathrm{~s}, 4 \mathrm{H})$.

N-(4-(8-Morpholinoimidazo[1,2-a]pyrazin-6-yl)phenyl)-6-(4-(trifluoromethyl)phenyl)pyrimidine-4-carboxamide (14g). A white solid; yield: 77.6\%; m.p. 278-281 ${ }^{\circ} \mathrm{C}$; ESI-MS $[\mathrm{M}+\mathrm{H}]^{+} \mathrm{m} / z: 546.2 ;{ }^{1} \mathrm{H}-\mathrm{NMR}\left(\mathrm{DMSO}-d_{6}\right)$ $\delta 10.86(\mathrm{~s}, 1 \mathrm{H}), 9.86(\mathrm{~d}, J=5.0 \mathrm{~Hz}, 1 \mathrm{H}), 8.49(\mathrm{~s}, 1 \mathrm{H}), 8.15(\mathrm{~d}, J=8.0 \mathrm{~Hz}, 2 \mathrm{H}), 8.10(\mathrm{~d}, J=4.5 \mathrm{~Hz}, 1 \mathrm{H})$, $8.03(\mathrm{dd}, J=20.1,8.6 \mathrm{~Hz}, 4 \mathrm{H}), 7.95(\mathrm{~d}, J=8.4 \mathrm{~Hz}, 3 \mathrm{H}), 7.59(\mathrm{~s}, 1 \mathrm{H}), 4.30(\mathrm{~s}, 4 \mathrm{H}), 3.80(\mathrm{~s}, 4 \mathrm{H})$.

\subsection{In Vitro Cytotoxicity Assays}

\subsubsection{The Selection of Cancer Cell Lines}

The studies of Yue showed that the expression of the VEGF, PI3K, Akt and mTOR genes of the PI3K-Akt-mTOR signaling pathway in non-small cell lung cancer (A549) were (40 \pm 59$) \%,(61 \pm 23) \%$, $(77 \pm 32) \%,(43 \pm 21) \%$ respectively [13]. The level of this pathway in breast cancer (MCF-7) was also up to 70\% [14]. In prostate cancer cells (PC-3), the missing tumor suppressor gene (PTEN) resulted in a high expression of the PI3K-Akt-mTOR signaling pathway. In addition, the studies of GDC-0941 showed it have strong inhibitory activity against A549, PC-3 and MCF-7 suggesting that these cells have a high sensitivity for PI3K-Akt_mTOR signaling pathway inhibitors [4]. Therefore, we chose these cell lines as the test cell lines for our in vitro anti-tumor experiments. 


\subsubsection{MTT Assay In Vitro}

The in vitro cytotoxic activity of all the compounds $12 \mathbf{a}-\mathbf{g}, 13 \mathbf{a}-\mathbf{g}$ and $14 \mathbf{a}-\mathbf{g}$ was evaluated with the A549, PC-3 and MCF-7 cell lines by the standard MTT assay, with compounds II and GDC-0941 as positive controls. The cancer cell lines were cultured in minimum essential medium (MEM) supplement with $10 \%$ fetal bovine serum (FBS). Approximately $4 \times 10^{3}$ cells, suspended in MEM medium, were plated onto each well of a 96-well plate and incubated in $5 \% \mathrm{CO}_{2}$ at $37^{\circ} \mathrm{C}$ for $24 \mathrm{~h}$. The test compounds at indicated final concentrations were added to the culture medium and the cell cultures were continued for $72 \mathrm{~h}$. Fresh MTT was added to each well at a terminal concentration of $5 \mu \mathrm{g} / \mathrm{mL}$ and incubated with cells at $37^{\circ} \mathrm{C}$ for $4 \mathrm{~h}$. The formazan crystals were dissolved in $100 \mu \mathrm{L}$ of DMSO in each well, and the absorbance at $492 \mathrm{~nm}$ (for the MTT formazan) and $630 \mathrm{~nm}$ (for the reference wavelength) was measured with an ELISA reader. All of the compounds were tested three times in each of the cell lines. The results expressed as inhibition rates or $\mathrm{IC}_{50}$ (half-maximal inhibitory concentration) were the averages of two determinations and calculated by using the Bacus Laboratories Incorporated Slide Scanner (Bliss) software (the Bacus Laboratories Inc. Slide Scanner (BLISS) system, Lombard, IL, USA).

\subsection{PI3Ka Kinase Assay}

The selected compounds $\mathbf{1 4 b}, \mathbf{1 4 c}$ were tested for their activity against PI3K $\alpha$ using a Kinase-Glo ${ }^{\circledR}$ Luminescent Kinase Assay, with Compound II, GDC-0941 and PI103 as positive controls. The kinase reaction is done in 384-well black plate. Each well is loaded with $50 \mu \mathrm{L}$ of test items (in $90 \%$ DMSO) and $5 \mu \mathrm{L}$ reaction buffer containing $10 \mu \mathrm{g} / \mathrm{mL}$ PI substrate (l- $\alpha$-phosphatidylinositol, Avanti Polar Lipids, (Avanti Polar Lipids, Inc., Alabaster, AL, USA), prepared in $3 \%$ octylglucoside) and the PI3K $\alpha$ protein $10 \mathrm{nM}$ is then added to it. The reaction is started by the addition of $5 \mu \mathrm{L}$ of $1 \mu \mathrm{M}$ ATP prepared in the reaction buffer and is incubated for $60 \mathrm{~min}$ for $\mathrm{p} 110 \alpha$. It is terminated by the addition of $10 \mu \mathrm{L}$ Kinase-Glo buffer. The plates are then read in a Synergy 2 reader (BioTek Instruments, Inc., Winooski, VT, USA) for luminescence detection. All of the compounds were tested two times $[9,10]$.

\subsection{Docking Studies}

For docking purposes, we prepared the receptor protein PDB ID code: 4L23 (PI3K $\alpha$ ). The three-dimensional structure of the PI3K $\alpha$ were obtained from the RCSB Protein Data Bank $[9,10]$. We built a small organic molecule set (compound 14c) and used the Gasteiger-Hückel method to optimize the molecular force field and structure. Hydrogen atoms were added to the structure allowing for appropriate ionization at physiological $\mathrm{pH}$. First of all, extract ligand substructure, then remove water and excess structure, finally, add hydrogens and fix sidechain amides. The protonated state of several important residues, such as Val851, Lys802, Ser773 and Asp933, were adjusted by using SYBYL 6.9.1 (Tripos, St. Louis, MO, USA) in favor of forming reasonable hydrogen bond with the ligand. Molecular docking analysis was carried out by the SURFLEX-DOCK module of SYBYL 6.9.1 package (Tripos) to explore the binding model for the active site of PI3K $\alpha$ with its ligand. All atoms located within the range of $5.0 \AA$ from any atom of the cofactor were selected into the active site, and the corresponding amino acid residue was, therefore, involved into the active site if only one of its atoms was selected. Other default parameters were adopted in the SURFLEX-DOCK calculations. All calculations were performed on a Silicon Graphics workstation (package version 6.9.1 on silicon graphics origin 300 workstation with IRIX 6.5 operating system, San Francisco, CA, USA). Lastly, docking results and the optimized molecular docking model with the receptor proteins was obtained.

\section{Conclusions}

Three new classes of 8-morpholino imidazo[1,2-a]pyrazine derivatives bearing phenylpyridinecarboxamides or phenylpyrimidine-carboxamides were designed, synthesized and evaluated for their cytotoxicity against three cancer cell lines and/or PI3K $\alpha$ kinase. The pharmacological results 
indicated that most of the synthesized compounds displayed moderate cytotoxicity against the three cell lines, with $\mathrm{IC}_{50}$ values ranging from 6.39 to $74.9 \mu \mathrm{M}$. The most promising compound 14c showed a good inhibitory activity against PI3K $\alpha$ kinase with an $\mathrm{IC}_{50}$ value of $1.25 \pm 0.13 \mu \mathrm{M}$, which was more potent than the lead compound II $\left(\mathrm{IC}_{50}\right.$ values $\left.7.39 \mu \mathrm{M}\right)$. Among them, the series of compounds containing phenylpyrimidine-carboxamide structures exhibited the best activity. For the other two series, the compounds with the aryl unit substituted at the pyridine $\mathrm{C}-4$ position were more active than those substituted at the C-5 position. Moreover, the substituents on the benzene ring also have an important impact on the cytotoxicity. The results demonstrated that electron donating groups on the benzene ring were beneficial to the cytotoxicity. The initial SARs and docking studies with the PI3K $\alpha$ molecule showed that the morpholine group, imidazopyrazine and amide scaffold were beneficial for these compounds to maintain a good activity.

Acknowledgments: We gratefully acknowledge the generous support provided by the National Natural Science Funds of China (No. 81460527), Science and Technology Project of Jiangxi Science \& Technology Normal University (2016XJZD007), the National Natural Science Funds of Jiangxi Province, China (20161BAB215216), Program of Key Laboratory of Drug Design and Optimization, Jiangxi Science \& Technology Normal University (300098010306), College Students' Science and Technology Innovation Project of Jiangxi Province.

Author Contributions: S.X., C.C. and C.S. synthesized all of novel compounds, P.Z., Y.Z. and H.Z. run the bioassay evaluation and statistics analysis, W.Z. started the project and designed the molecules, S.X. and C.S. wrote the paper.

Conflicts of Interest: The authors declare no conflict of interest.

\section{References}

1. Rodon, J.; Dienstmann, R.; Serra, V.; Tabernero, J. Development of PI3K inhibitors: Lessons learned from early clinical trials. Nat. Rev. Clin. Oncol. 2013, 10, 143-153. [CrossRef] [PubMed]

2. Janku, F.; Wheler, J.J.; Westin, S.N.; Moulder, S.L.; Naing, A.; Tsimberidou, A.M.; Fu, S.; Falchook, G.S.; Hong, D.S.; Garrido-Laguna, I.; et al. PI3K/AKT/mTOR inhibitors in patients with breast and gynecologic malignancies harboring PIK3CA mutations. J. Clin. Oncol. 2012, 30, 777-782. [CrossRef] [PubMed]

3. Hayakawa, M.; Kaizawa, H.; Moritomo, H.; Koizumi, T.; Ohishi, T.; Yamano, M.; Okada, M.; Ohta, M.; Tsukamoto, S.; Raynaud, F.I.; et al. Synthesis and biological evaluation of pyrido $\left[3^{\prime}, 2^{\prime}: 4,5\right]$ furo[3,2-d]pyrimidine derivatives as novel PI3 kinase p110á inhibitors. Bioorg. Med. Chem. Lett. 2007, 17, 2438-2442. [CrossRef] [PubMed]

4. Folkes, A.J.; Ahmadi, K.; Alderton, W.K.; Alix, S.; Baker, S.J.; Box, G.; Chuckowree, I.S.; Clarke, P.A.; Depledge, P.; Eccles, S.A.; et al. The identification of 2-(1H-Indazol-4-yl)-6-(4-methanesulfonyl-piperazin-1-yl methyl)-4-morpholin-4-yl-thieno[3,2- $d$ ]pyrimidine (GDC-0941) as a potent, selective, orally bioavailable inhibitor of class I PI3 kinase for the treatment of cancer. J. Med. Chem. 2008, 51, 5522-5532. [CrossRef] [PubMed]

5. Hsieh, A.C.; Liu, Y.; Edlind, M.P.; Ingolia, N.T.; Janes, M.R.; Sher, A.; Shi, E.Y.; Stumpf, C.R.; Christensen, C.; Bonham, M.J.; et al. The translational landscape of mTOR signalling steers cancer initiation and metastasis. Nature 2012, 485, 55-61. [CrossRef] [PubMed]

6. Venkatesan, A.M.; Dehnhardt, C.M.; Delos Santos, E.; Chen, Z.; Dos Santos, O.; Ayral-Kaloustian, S.; Khafizova, G.; Brooijmans, N.; Mallon, R.; Hollander, I.; et al. Bis (morpholino-1,3,5-triazine) derivatives: Potent adenosine 5'-triphosphate competitive phosphatidylinositol-3-kinase/mammalian target of rapamycin inhibitors: Discovery of compound 26 (PKI-587), a highly efficacious dual inhibitor. J. Med. Chem. 2010, 53, 2636-2645. [CrossRef] [PubMed]

7. Martínez González, S.; Hernández, A.I.; Varela, C.; Lorenzo, M.; Ramos-Lima, F.; Cendón, E.; Cebrián, D.; Aguirre, E.; Gomez-Casero, E.; Albarrán, M.I.; et al. Rapid identification of ETP-46992, orally bioavailable PI3K inhibitor, selective versus mTOR. Bioorg. Med. Chem. Lett. 2012, 22, 5208-5214. [CrossRef] [PubMed]

8. Zhu, W.; Sun, C.; Xu, S.; Wu, C.; Wu, J.; Xu, M.; Zhao, H.; Chen, L.; Zeng, W.; Zheng, P. Design, synthesis, anticancer activity and docking studies of novel 4-morpholino-7,8-dihydro-5H-thiopyrano[4,3- $d$ ] pyrimidine derivatives as mTOR inhibitors. Bioorg. Med. Chem. 2014, 22, 6746-6754. [CrossRef] 
9. Lei, F.; Sun, C.; Xu, S.; Wang, Q.; OuYang, Y.; Chen, C.; Xia, H.; Wang, L.; Zheng, P.; Zhu, W. Design, synthesis, biological evaluation and docking studies of novel 2-substituted-4-morpholino-7,8-dihydro-5 $\mathrm{H}$ thiopyrano[4,3- $d$ ]pyrimidine derivatives as dual PI3K $\alpha / \mathrm{mTOR}$ inhibitors. Eur. J. Med. Chem. 2016, 116, 27-35. [CrossRef] [PubMed]

10. Sun, C.; Chen, C.; Xu, S.; Wang, J.; Zhu, Y.; Kong, D.; Tao, H.; Jin, M.; Zheng, P.; Zhu, W. Synthesis and anticancer activity of novel 4-morpholino-7,8-dihydro-5H-thiopyrano[4,3-d]pyrimidine derivatives bearing chromone moiety. Bioorg. Med. Chem. 2016, 24, 3862-3869. [CrossRef] [PubMed]

11. Liu, H.; Wang, W.; Sun, C.; Wang, C.; Zhu, W.; Zheng, P. Synthesis and Biological Evaluation of Novel 4-Morpholino-7,8-dihydro-5H-thiopyrano[4,3- $d]$ pyrimidine Derivatives Bearing Phenylpyridine/ Phenylpyrimidine-Carboxamides. Molecules 2016, 21, 1447. [CrossRef] [PubMed]

12. Zhu, W.; Wang, W.; Xu, S.; Wang, J.; Tang, Q.; Wu, C.; Zhao, Y.; Zheng, P. Synthesis, and docking studies of phenylpyrimidine-carboxamide derivatives bearing $1 \mathrm{H}$-pyrrolo[2,3- $b$ ]pyridine moiety as c-Met inhibitors. Bioorg. Med. Chem. 2016, 24, 1749-1756. [CrossRef] [PubMed]

13. Yue, W.; Wang, X.; Wang, Y. The Relationship between the PI3K/Akt/mTOR Signal Transduction Pathway and Non-small Cell Lung Cancer. Chin. J. Lung Cancer 2009, 12, 312-315.

14. López-Knowles, E.; O’Toole, S.A.; McNeil, C.M.; Millar, E.K.; Qiu, M.R.; Crea, P.; Daly, R.J.; Musgrove, E.A.; Sutherland, R.L. PI3K pathway activation in breast cancer is associated with the basal-like phenotype and cancer-specific mortality. Int. J. Cancer 2010, 126, 1121-1131. [CrossRef] [PubMed]

Sample Availability: Samples of the compounds 12a-g, 13a-g and 14a-g are available from the authors.

(C) 2017 by the authors; licensee MDPI, Basel, Switzerland. This article is an open access article distributed under the terms and conditions of the Creative Commons Attribution (CC BY) license (http:/ / creativecommons.org/licenses/by/4.0/). 